\title{
Evaluation of Acute Toxicity and Survival in Children with Acute Myeloid Leukemia Treatment: A Single-Center Retrospective Study from a Middle- Income Country
}

\section{Akut Miyeloid Lösemi Tedavisi Alan Çocuklarda Akut Toksisite, Genel ve Olaysız Sağkalımın Değerlendirilmesi: Orta Gelir Düzeyli Bir Ülkeden Tek Merkezli Retrospektif Kesitsel Bir Çalıșma}

\author{
(1) Ali Ayçiçek1, (1) Elif Böncüoğlu2, (1) Cengiz Bayram¹, (D) Ezgi Paslı Uysalol1, (1) Gül Nihal Özdemirl, (D) Müge Gökçel, \\ (D) Gönül Aydoğanl, (D) Zafer Șalcıoğlul, (D) Ferhan Akıcıl', (D) Ișık Odaman All, (D) Gizem Ersoyl, \\ (D) Tuba Nur Tahtakesen Güçerl \\ IUniversity of Health Sciences Turkey, Kanuni Sultan Süleyman Training and Research Hospital, Clinic of Pediatric Hematology and Oncology, İstanbul, Turkey \\ 2University of Health Sciences Turkey, Kanuni Sultan Süleyman Training and Research Hospital, Clinic of Pediatrics, İstanbul, Turkey
}

\begin{abstract}
Objective: This study aimed to evaluate the acute toxicity, overall survival (OS), and event-free survival (EFS) of children diagnosed and treated for acute myeloid leukemia.

Method: This study includes a total of 43 patients (age range: 1-18 years) who were diagnosed and treated from 2011 to 2016 at a pediatric hematology and oncology clinic at a teaching hospital in Turkey. The patient files were retrospectively analyzed.

Results: Of the 43 patients, 22 (51.2\%) were boys and 21 (48.8\%) were girls. The mean age at the time of diagnosis was $7.39 \pm 4.7$ years. Fourteen (32.6\%) patients were classified as standard-risk, 15 (34.9\%) intermediate-risk, and $11(25.6 \%)$ high-risk group. Information about risk groups of three patients was missing in the medical records. Two patients were lost due to acute toxicity and four were lost due to infection after induction therapy. Bone marrow relapse occurred in three (6.9\%) patients who had completed induction therapy and had bone marrow remission. The median follow-up period was 29 months (range: 1-74 months). The estimated 5-year OS and EFS were found to be $76 \% \pm 6.6 \%$ and $66 \% \pm 9.3 \%$, respectively. The estimated 2-year 0S for standard, intermediate, and high-risk groups was $77 \% \pm 12 \%, 77 \% \pm 10 \%$, and $82 \% \pm 12 \%$, respectively, while EFS was $77 \% \pm 12 \%, 70 \% \pm 11 \%$, and $73 \% \pm 13 \%$, respectively ( $p>0.05$ ). Conclusion: The OS and EFS were positively favored with the current median follow-up. The study should be repeated with more patients and longer follow-up periods.

Keywords: Acute myeloid leukemia, children, survival rate
\end{abstract}

Cite as: Ayçiçek A, Böncüoğlu E, Bayram C, Paslı Uysalol E, Özdemir GN, Gökçe M, Aydoğan G, Şalcıŏlu Z, Akıcı F, Odaman Al I, Ersoy G, Tahtakesen Güçer TN. Evaluation of Acute Toxicity and Survival in Children with Acute Myeloid Leukemia Treatment: A Single-Center Retrospective Study from a Middle-Income Country. IKSSTD 2021;13(2):92-7

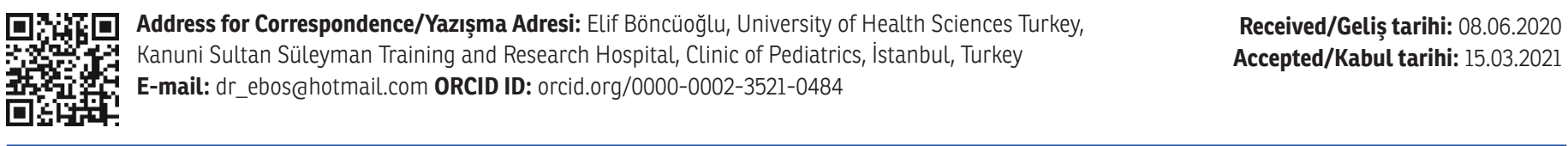

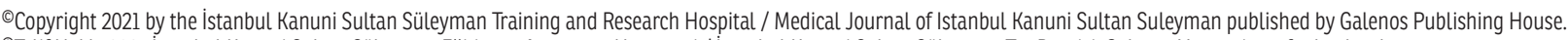
๑Telif Hakkı 2021 İstanbul Kanuni Sultan Süleyman Eğitim ve Araștırma Hastanesi / Istanbul Kanuni Sultan Süleyman Tıp Dergisi, Galenos Yayınevi tarafindan basılmıștı. 
ÖZ

Amaç: Bu çalıșma, akut miyeloid lösemi tedavisi alan çocuklarda akut toksisiteyi, genel sağkalım (GS) ve olaysız sağkalımı (OS) değerlendirmeyi amaçlamaktadır.

Yöntem: Bu çalışma, Türkiye'de bir eğitim hastanesinde, 2011-2016 yılları arasında pediatrik hematoloji ve onkoloji kliniğinde tanı alan ve tedavi edilen 1-18 yaş arasındaki 43 hastayı içermektedir. Hasta dosyaları retrospektif olarak incelenmiștir.

Bulgular: Yirmi iki $(\% 51,2)$ hasta erkek, $21(\% 48,8)$ hasta kızdı. Tanı sırasındaki ortalama yaş 7,39 $\pm 4,7$ idi. On dört $(\% 32,6)$ hasta standart risk, $15(\% 34,9)$ orta risk ve $11(\% 25,6)$ hasta yüksek risk grubundaydı. Tıbbi kayıtlarda 3 hastanın risk grupları hakkında bilgi yoktu. Iki hasta akut toksisite nedeniyle ve dört hasta indüksiyon tedavisi sonrası enfeksiyon nedeniyle kaybedildi. Kemik iliği relapsı, indüksiyon tedavisini tamamlamış ve kemik iliği remisyonu olan $3(\% 6,9)$ hastada meydana geldi. Ortanca takip süresi 29 aydı (1-74 ay). Beş yıllık genel sağkalım ve 0 s sırasılyla $\% 76 \pm 6,6$ ve $\% 66 \pm 9,3$ olarak bulundu. Standart, orta ve yüksek riskli gruplar için 2 yıllık GS sırasılyla $\% 77 \pm 12, \% 77 \pm 10$ ve $\% 82 \pm 12$ idi. OS sırasılla $\% 77 \pm 12, \% 70 \pm 11$ ve $\% 73 \pm 13$ idi $(p>0,05)$.

Sonuç: Mevcut ortanca takip süresi ile GS ve OS'ler iyi düzeydedir. Çalıșma daha fazla sayıda hasta ve daha uzun takip süreleriyle tekrarlanmalıdır.

Anahtar kelimeler: Akut miyeloid lösemi, çocuklar, sağkalım oranı

\section{INTRODUCTION}

Acute myeloid leukemia (AML) is the clonal transformation of myeloid cell precursors, which acquire abnormalities in their self-renewal, proliferation, and differentiation potential (1). It represents $15 \%-20 \%$ of childhood leukemia ${ }^{(2)}$. In recent years, overall survival (OS) has increased with risk-oriented chemotherapy regimens, development of supportive therapies, use of minimal residual disease in the evaluation of response to treatment, and increased experience in bone marrow transplantation. Administration of risk-oriented chemotherapy regimens and limiting intensive treatment protocols, including bone marrow transplantation, to highrisk groups have reduced the risk of treatment-related morbidity and mortality (3). However, $30 \%$ of childhood leukemia-related deaths are caused by AML due to resistant disease or treatment-related toxicity ${ }^{(4)}$. There is limited data regarding pediatric AML in Turkey in the past decade. This study aimed to evaluate the acute toxicity, OS, and eventfree survival (EFS) of a total of 43 AML cases between 2011 and 2016 at pediatric hematology and oncology clinic in a tertiary research and training hospital.

\section{MATERIAL and METHODS}

A total of 181 patients with acute leukemia who were followed up in our center were detected from the records of the Turkish Pediatric Oncology Group and 136 patients with acute lymphoblastic leukemia were excluded. Two of the remaining 45 patients with $A M L$ who were infants (< 1 year) were also excluded from the study due to the unique clinical characteristics and different prognostic features of infant leukemias. A total of 43 patients with AML (aged ranged: 1-18 years) who were diagnosed and treated from 2011 to 2016 at the pediatric hematology and oncology clinic at our hospital, a tertiary referral hospital in İstanbul. The patient files were retrospectively analyzed. The treatment protocols used in our clinic between 2011 and 2016 were AML-BFM 2004, AML-BFM 2012, MRC-AML 12, and MRC-AML 15.

Ethical approval for this study was obtained from Bezmialem Vakıf University Non-Interventional Clinical Research Ethics Committee (approval number: 17/252).

\section{Definitions}

OS was defined as the time from the date of diagnosis to death from any cause or the date of the last contact. EFS was defined as the time from remission until the date of failure (induction failure, relapse, or death) or until the date of the last contact for all event-free survivors.

\section{Statistical Analysis}

The distribution of data was compared with the K-S Lilliefors test. The proportions of independent groups were compared by chi-square test and Student's t-test. Comparison between mean values in our study and literature data was performed by one-sample t-test. Survival rates of the groups were calculated by the Kaplan-Meier method and compared by two-way log-rank analysis. Follow-up times and survival rates were given as mean \pm standard error of mean (mean \pm SEM). P values less than 0.05 were considered statistically significant. All statistical analysis was performed with IBM SPSS Statistics for Windows, Version 22.0. (IBM Corp., Armonk, NY, USA).

\section{Risk Groups}

The patients had been divided into risk groups according to the risk classifications of AML-BFM 2004, AML-BFM 2012, MRC-AML 12, and MRC-AML 15 protocols. Due to the small number of cases, when evaluating survival according to risk groups, cases in the low-risk group according to MRC-AML protocols were included in the standard-risk group according 
to BFM AML protocols. Patients in the standard-risk group according to MRC AML protocols were included in the intermediate-risk group according to BFM AML protocols.

\section{RESULTS}

Of the 181 acute leukemia cases, 43 (24.8\%) was AML. Of the 43 patients with AML, 22 (51.2\%) were boys and 21 (48.8\%) were girls. The female/male ratio was $1 / 1.04$. The youngest patient included in the study was 1.08 years old and the oldest patient was 15.95 years old. The mean age at the time of diagnosis was $7.4 \pm 4.7$ years. Due to the continuation of their treatment in other centers, three cases were not followed up. Of the remaining 43 patients with $A M L, 14$ (33\%) were classified as standart-risk, 15 (35\%) were intermediate-risk, and 11 (26\%) were high-risk group. Information about risk groups of three patients were missing in the medical records. Two patients were lost due to acute toxicity and four were lost due to infection after induction therapy. Bone marrow relapse occurred in three (6.9\%) out of $43(100 \%)$ patients who completed induction therapy and had bone marrow remission.

The median duration follow-up was 29 months (range: 1-74 months). The estimated 5-year OS and EFS were $76 \% \pm 6.6 \%$ and $66 \% \pm 9.3 \%$, respectively. The estimated 2-year OS for standard, intermediate, and high-risk groups was $77 \% \pm$ $12 \%, 77 \% \pm 10 \%$, and $82 \% \pm 12 \%$, respectively (Figure 1 ). On the other hand, EFS was $77 \% \pm 11,7 \%, 88 \% \pm 7,8 \%$, and $73 \% \pm 13.4 \%$, respectively ( $p>0.05$ ) (Figure 2$)$. There was no statistically significant difference between gender and risk groups in terms of OS and EFS ( $p>0.05)$.

The 2-year OS rate of girls and boys were $80 \% \pm 8.8 \%$ and $72 \% \pm 9.8 \%$, respectively (Figure 3 ), while the EFS rate was $80 \% \pm 8.8 \%$ and $62 \% \pm 11 \%$, respectively ( $p>0.05$ ). Twelve (28\%) patients received bone marrow transplantation (BMT). The OS rate of the intermediate and high-risk group who received BMT was slightly better in the median follow-up period of 27 months (range: 2.9 to 74 months) compared with the non-BMT group ( $p=0.132$ ), while the EFS was similar ( $p$ $=0.627$ ).

\section{DISCUSSION}

Acute leukemia accounts for approximately 30\% of all childhood cancers ${ }^{(5)}$. AML is a rare type of leukemia in childhood. In the US and other developed countries, about $15 \%$ of all leukemia cases are AML ${ }^{(4)}$. The average incidence in our country is not clear due to the lack of studies in childhood AML. This is the first single-center study regarding the survival rates of patients with pediatric AML. In our study, $24.8 \%$ of all leukemia cases were AML and the male/female ratio was $1 / 1.04$, which is compatible with the data in the literature regarding the sex frequency of AML ${ }^{(4,6,7)}$. In a multicentric national study conducted by the Turkish Pediatric Hematology Association in Turkey, which includes a total of 194 patients diagnosed between 2005 and 2010 and treated according to AML-BFM protocol, the mean age of the patients was $8.7 \pm 7.9$ months [Ozyurek $E$, Vergin C, Büyükavcı $M$, et al. The outcomes of Turkish children with AML treated on AML-Berlin-Munster-Frankfurt (AMLBFM) protocol: Turkish AML-BFM Study Group. In: $4^{\text {th }}$ International Congress on Leukemia Lymphoma Myeloma (Abstracts); 22-25 May; İstanbul, Turkey, 2013]. In our study, the mean age was lower with $7.4+4.7$, but the difference was not statistically significant. The development of riskoriented chemotherapy regimens, supportive therapies, use of minimal residual disease in the evaluation of response to treatment, and increase in experience in BMT lead to an increase in 5-year OS from $20 \%$ to $68 \%$ under the age of 15 and from $20 \%$ to $57 \%$ in adolescents between the age range
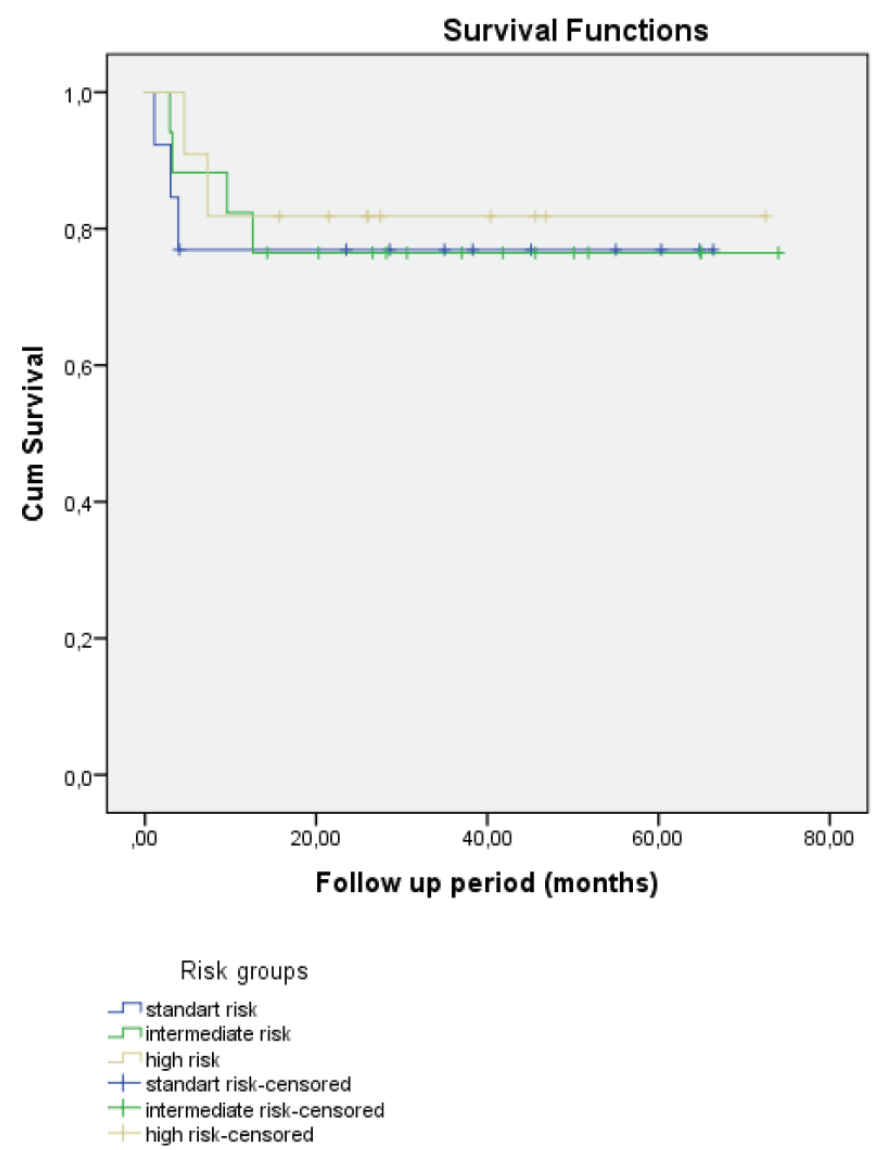

Figure 1. Overall survival according to risk groups 
of $15-19$ from 1975 to $201{ }^{(4)}$. The EFS rates in developed countries have reached $>60 \%{ }^{(8,9)}$. However, relapse rates are still within the range of $25 \%-30 \%{ }^{(10)}$. According to the United States National Surveillance Epidemiology and End Results data, the 5-year survival rate of children diagnosed under the age of 15 is $64.3 \%$ (11). In another study by the Tokyo Children's Cancer Study Group, the 5-year OS was $62 \%{ }^{(12)}$. In the AML99 study conducted in Japan, the 5 -year OS and EFS were $75.6 \%$ and $61.6 \%$, respectively ${ }^{(13)}$. In middle and low-income countries, childhood AML survival rates are lower considerably. For instance, a study conducted in El Salvador showed that the 5-year EFS and OS were $23.6 \%$ and $28.3 \%$, respectively ${ }^{(14,15)}$. In Iran, Mehrvar et al. ${ }^{(16)}$ reported that the 3 -year OS was $42 \%$. In our country, in a multicenter study (AML-BFM Turkey), the OS and EFS were $58.8 \%$ and $58.4 \%$, respectively. According to another study conducted at Kocaeli University, a university hospital in northwestern Turkey, a total of 49 patients had a 6-year EFS rate of $42.9 \%$ and an OS rate of $61.2 \%{ }^{(17)}$. In our study,
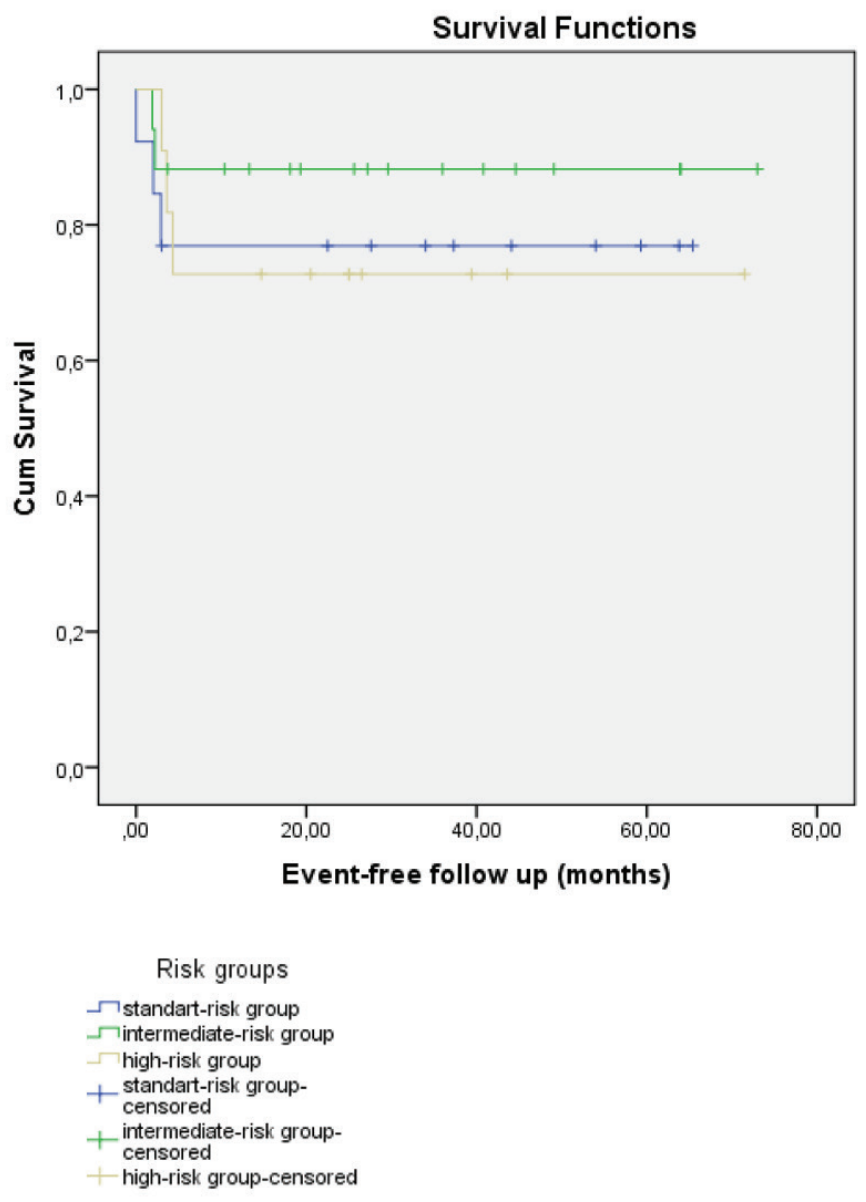

Figure 2. Event-free survival according to risk groups the 2-year OS and EFS were $76 \% \pm 6.6 \%$ and $71 \% \pm 7.1 \%$, respectively. Accordingly, the ratio of OS and EFS with a 29-month follow-up was above those of other centers in Turkey and has reached the level in developed countries. However, it is necessary to repeat the study with a longer follow-up period. Studies on the effect of gender on survival in childhood $A M L$ are ongoing and data on this issue are limited. In some studies, the male gender showed a slight predominance to the females $(1.2: 1){ }^{(18,19)}$. According to a study conducted in the USA, which includes those within the age range of 0-24 years, the 5-year survival was $51 \%$ in girls and $46 \%$ in boys and the difference between the groups was statistically significant ${ }^{(20)}$. In our study, although the EFS rate was lower in the male cases, no statistically significant difference was found between the groups in terms of survival. It is suggested that this is due to the small number of cases in our study. When evaluated according to the risk groups, no statistically significant difference was found between the groups in terms of OS and EFS. In 11 cases in the standard-risk group, certain events were observed in 3 cases. One of them was relapse, which had been followed (disease-free) after treatment. The

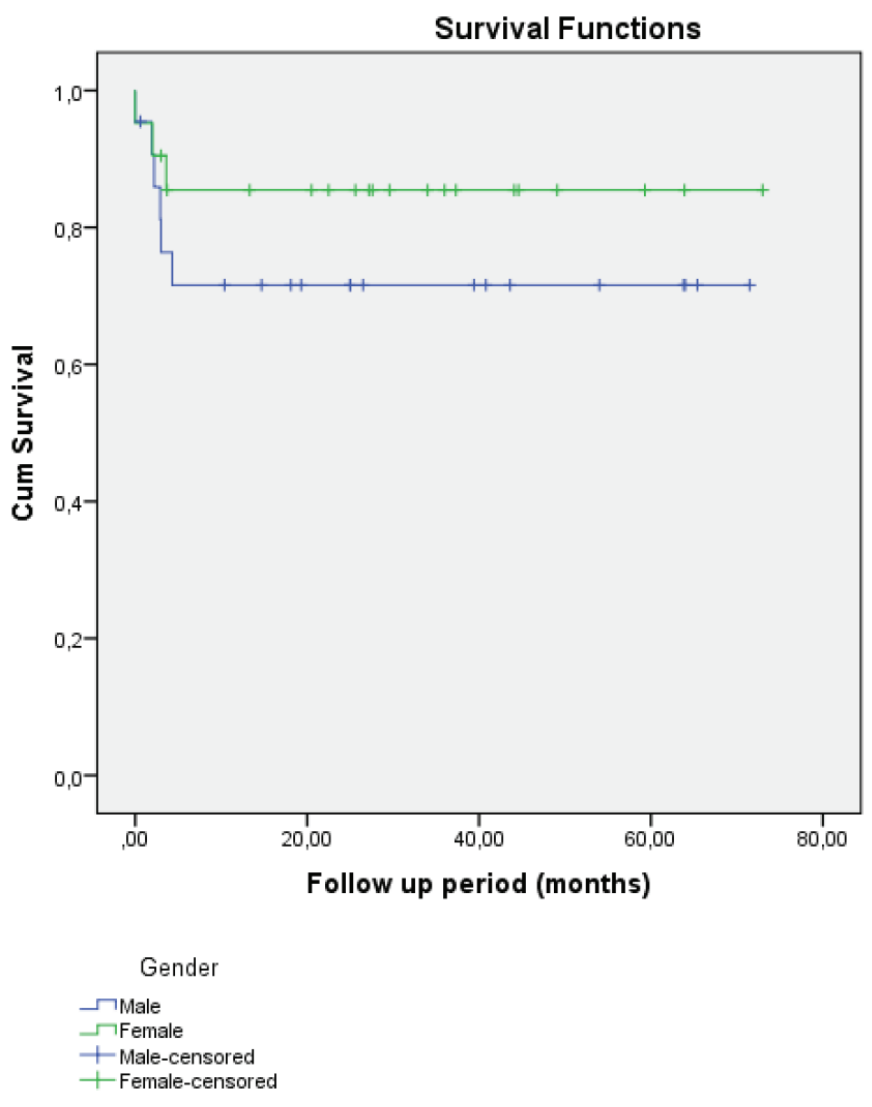

Figure 3. Overall survival according to gender 

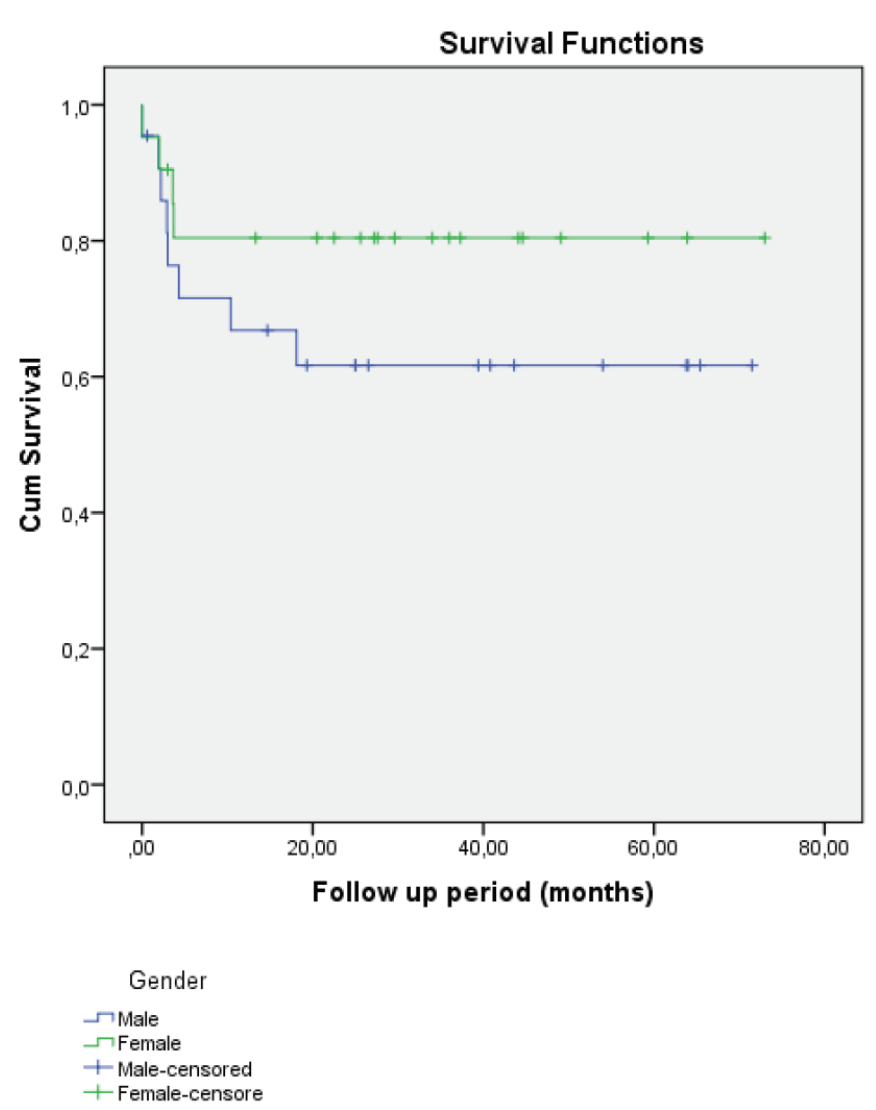

Figure 4. Event-free survival according to gender

other two patients died due to sepsis, although they were in remission. The lower EFS rate in the standard-risk group was attributed to these three events. On the other hand, the OS and EFS rate in the high-risk group were as good as in the standard-risk group, which can be attributed to the disease-free follow-up of the three patients with BMT in the high-risk group. Intensification of chemotherapy regimens not only increased survival, but also increased morbidity and mortality due to toxicity. Studies have reported that early deaths related to treatment are seen in 5\%-13\% of the cases. Deaths due to toxicity seen during induction treatment are mostly associated with bleeding, leukostasis, and infection ${ }^{(21-23)}$. A study by Silva et al. ${ }^{(24)}$ reports that the death rates associated with the treatment of AML in less developed countries have reached up to $33 \%$. In our study, 2 cases $(4.6 \%)$ died due to acute toxicity during the followup period. Precisely, one of them died due to infection and the other died due to intracranial hemorrhage. Although allogeneic BMT as post-remission consolidation therapy is associated with low relapse, it has not been proven superior over chemotherapy treatment regimens in terms of OS ${ }^{(25-27)}$. The transplantation decision should be made, taking into account transplant-related mortality and long-term toxicity according to remission status, risk group, donor type, and tissue compliance. Accordingly, it is recommended that allogeneic BMT be limited to intermediate and high-risk groups or patients with relapse (28). In our study, the OS and EFS rates were found to be better, but were not statistically different $(p=0.132)$ in patients with BMT in the intermediate and high-risk group compared with the standard-risk group. Although the most probable reason for this is the small number of cases, we consider that having similar survival rates in the high and standard-risk group patients within the current follow-up period (median 29-months) is a significant success based on the literature reports that the events occurred as the most intense in the first two years ${ }^{(29)}$.

\section{Study Limitations}

The limitations of our study can be listed as obtaining data from patient files due to the retrospective nature of the study, missing data, limited number of cases for subgroups, short follow-up periods, different treatment protocols, and classification criteria applied to the patients.

\section{CONCLUSION}

This study showed a low rate of acute toxicity due to childhood AML treatment in our center. In the current median follow-up period, OS and EFS rates were similar to those of developed countries. Allogeneic BMT does not contribute significantly to the survival in intermediate and high-risk groups. This study should be repeated with more cases and longer follow-up periods.

Ethics Committee Approval: Ethics approval for this study was obtained from Bezmialem Vakıf University NonInterventional Clinical Research Ethics Committee (approval number: 17/252).

Informed Consent: Informed consent was obtained from the legal guardians of the patients.

Conflict of Interest: No conflict of interest was declared by the authors.

Financial Disclosure: The authors declared that this study received no financial support.

Etik Kurul Onayı: Bu çalışma için etik onay Bezmialem Vakıf Üniversitesi Girişimsel Olmayan Klinik Araştırmalar Etik Kurulu'ndan alınmıştır (onay numarası: 17/252).

Hasta Onayı: Hastaların yasal temsilcilerinden 
bilgilendirilmiş onam alındı.

\section{Çıkar Çatıșması: Yazarlar tarafından çıkar çatışması} bildirilmemiştir.

Finansal Destek: Yazarlar tarafından finansal destek almadıkları bildirilmiştir.

\section{REFERENCES}

1. Rubnitz JE. Current Management of Childhood Acute Myeloid Leukemia. Pediatr Drugs. 2016;19:1-10. 10.1007/s40272-016-0200-6.

2. Creutzig $U$, Buchner T, Sauerland MC, et al. Significance of age in acute myeloid leukemia patients younger than 30 years: a common analysis of the pediatric trials AML-BFM 93/98 and the adult trials AMLCG 92/99 and AMLSG HD93/98A. Cancer. 2008;112:562-571. doi: 10.1002/ cncr.23220.

3. van der Velden VH, van der Sluijs-Geling A, Gibson BE, et al. Clinical significance of flowctometric minimal residual disease detection in pediatric acute myeloid leukemia patients treated according to the DCOG ANLL97/MRC AML12 protocol. Leukemia. 2010;24:1599-606. doi: 10.1038/Leu.2010.153. Epub 2010 Jul 29.

4. Weinblatt ME. Pediatric acute myelocytic leukemia. [Emedicine, Medscape Referance]. Sep 12, 2017. Available at: https://emedicine. medscape.com/article/987228-overview\#a5. Accessed August 25, 2019.

5. Lanzkowsky P. Leukemias. Manual of Pediatric Hematology and Oncology 4th ed Churchill livingstan Nek, London, Madrid. 2011;17:51866.

6. Hjalgrim LL, Rostgaard K, Schmiegelow K, et al. Age and Sex-Specific incidence of childhood leukemia by immunophenotype in the Nordic countries. J Natl Cancer Inst 2003;95:1539-44. doi: 10.1093/jnci/djg064.

7. Mejía-Aranguré JM, Fajardo-Gutiérrez A, Flores-Aguilar $H$, et al. Environmental Factors contributing to the development of childhood leukemia in children with Down's syndrome. Leukemia 2003;17:1905-7. doi: 10.1038/sj.leu.2403047.

8. Marjerrison S, Antillon F, Bonilla M, et al. Outcome of children treated for relapsed acute myeloid leukemia in Central America. Pediatr Blood Cancer. 2014;61:1222-6. doi: 10.1002/pbc.24942.

9. Pui $\mathrm{CH}$, Carroll $\mathrm{WL}$, Meshinchi $\mathrm{S}$, et al. Biology, risk stratification, and therapy of pediatric acute leukemias: an update. J Clin Oncol. 2011;29:4847 29(25):551-565. doi: 10.1200/JC0.2010.30.7405.

10. Zwaan CM, Kolb EA, Reinhardt D, et al. Collaborative Efforts Driving Progress in Pediatric Acute Myeloid Leukemia. J Clin Oncol. 2015;33:2949-62. doi: 10.1200/JC0.2015.62.8289.

11. Howlader N, Noone AM, Krapcho M, et al. SEER Cancer Statistics Review, 1975-2009 (Vintage 2009 Populations) National Cancer Institute; Bethesda, MD: 2012. Available at: https://seer.cancer.gov/ archive/csr/1975_2009_pops09/. Accessed August 25, 2019.

12. Tomizawa D, Tabuchi K, Kinoshita A, et al. Repetitive cycles of high dose cytarabine are effective for childhood acute myeloid leukemia: longterm outcome of the children with AML treated on two consecutive trials of Tokyo Children's Cancer Study Group. Pediatr Blood Cancer. 2007; 49:127-32. doi: 10.1002/pbc.20944.

13. Imamura $T$, Iwamoto $S$, Kanai $R$, et al. Outcome in 146 patients with paediatric acute myeloid leukemia treated according to the AML99 protocol in the period 2003-06 from the Japan Association of Childhood Leukemia Study. Br J Haematol. 2012;159:204-10. doi: 10.1111/bjh.12030.

14. Gupta S, Bonilla M, Fuentes SL, et al. Incidence and predictors of treatment-related mortality in paediatric acute leukaemia in $\mathrm{El}$
Salvador. Br J Cancer. 2009;100:1026-31. doi: 10.1038/sj.bjc.6604895. Epub 2009 Mar 17.

15. Marjerrison S, Antillon F, Fu L, et al. Outcome of children treated for relapsed acute lymphoblastic leukemia in Central America. Cancer. 2013;119:1277-83. doi: 10.1002/cncr.27846. Epub 2012 Nov 16.

16. Mehrvar A, Rahiminejad MS, Hedayati AsL AA, et al. Features of Childhood Acute Myeloid Leukemia in Iran: a Report from Double Center Study. Acta Med Iran. 2015;53:749-52.

17. Zengin E, Sarper N, Aylan Gelen S, et al. High infection-related mortality in pediatric acute myeloid leukemia without preventive antibiotics and antifungals: retrospective cohort study of a single center from a middle-income country. Turk J Haematol. 2017 Dec 1;34:340-344. doi: 10.4274/tjh.2017.0052. Epub 2017 Mar 29.

18. Viana MB, Cunha KC, Ramos G, et al. Leucemia mieloide aguda na crianc,a: experiência de 15 anos em uma única instituic,ão. J Pediatr (Rio J). 2003;79:489-96.

19. Kavcic M, Fisher BT, Torp K, et al. Assembly of a cohort of children treated for acute myeloid leukemia at free-standing children's hospitals in the United States using an administrative database. Pediatr Blood Cancer. 2013;60:508-11. doi: 10.1002/pbc.24402. Epub 2012 Nov 28.

20. Hossain J, Xie L. Sex disparity in childhood and young adult acute myeloid leukemia (AML) survival: evidence from US population data. Cancer Epidemiol. 2015;39:892-900. oi: 10.1016/j.canep.2015.10.020. Epub 2015 Nov 9.

21. Riley LC, Hann IM, Wheatley K, et al. Treatment-related deaths during induction and first remission of acute myeloid leukaemia in children treated on the Tenth Medical Research Council acute myeloid leukaemia trial (MRC AML10). The MCR Childhood Leukaemia Working Party. Br J Haematol. 1999;106:436-44.

22. Creutzig U, Zimmermann M, Reinhardt D, et al. Early deaths and treatment-related mortality in children undergoing therapy for acute myeloid leukemia: analysis of the multicenter clinical trials AML-BFM 93 and AML-BFM 98. J Clin Oncol. 2004;22:4384-93. doi: 10.1200/ JCO.2004.01.191.

23. Hann IM, Stevens RF, Goldstone AH, et al. Randomized comparison of DAT versus ADE as induction chemotherapy in children and younger adults with acute myeloid leukemia. Results of the Medical Research Council's 10th AML trial (MRC AML10). Adult and Childhood Leukaemia Working Parties of the Medical Research Council. Blood. 1997;89:2311-8.

24. Silva FF, Zandonade E, Zouain-Figueiredo GP. Analysis of childhood leukemia mortality trends in Brazil, from 1980 to 2010. J Pediatr (Rio J). 2014;90:587---92.

25. Horan JT, Alonzo TA, Lyman GH, et al. Impact of disease risk on efficacy of matched related bone marrow transplantation for pediatric acute myeloid leukemia: the Children's Oncology Group. J Clin Oncol. 2008;26:5797-5801

26. Klingebiel T, Reinhardt D, Bader P. Place of HSCT in treatment of childhood AML. Bone Marrow Transplant 2008;42:S7-9.

27. Niewerth $D$, Creutzig $U$, Bierings $M B$, et al. A review on allogeneic stem cell transplantation for newly diagnosed pediatric acute myeloid leukemia. Blood 2010;116:2205-14.

28. Perel Y, Auvrignon A, Leblanc T, et al. Treatment of childhood acute myeloblastic leukemia: dose intensification improves outcome and maintenance therapy is of no benefit-multicenter studies of the French LAME (Leucemie Aigue Myeloblastique Enfant) Cooperative Group. Leukemia. 2005;19:2082-9.

29. Burnusuzov HA, Yordanova MN, Avramova BE, et al. Treatment of Childhood Acute Myeloid Leukemia in Bulgaria. Folia Med (Plovdiv). 2018;60:234-40. doi: 10.1515/folmed-2017-0090. 